\title{
Kewenangan Hakim Pengadilan Negeri Dalam Mengadili Pembagian Harta Warisan Setelah Berlakunya Undang-undang 50 Tahun 2009 Tentang Peradilan Agama
}

\author{
Marwan Busyro \\ marwan.busyro@um-tapsel.ac.id
}

\section{(Staf Pengajar Fakultas Hukum UMTS Padangsidimpuan)}

\begin{abstract}
ABSTRAK
Berdasarkan judul penelitian seperti yang tersebut di atas dimana kita ketahui bahwa masalah harta warisan ini sangat sering sekali terjadinya persengkataan antara keluarga, maka penulis perlu melakukan penelitian tentang kewenangan Hakim Pengadilan Negeri dalam mengadili harta warisan setelah berlakunya Undang-undang Nomor 50 Tahun 2009 tentang Peradilan Agama tersebut. Tujuan penelitian adalah untuk mengetahui kewenangan Hakim Pengadilan Negeri mengadili perkara pembagian harta warisan setelah berlakunya Undang-undang Nomor 50 Tahun 2009 tentang Peradilan Agama dan untuk mengetahui bagaimana kekuatan hukumnya pembagian harta warisan yang disidangkan di Pengadilan Negeri Padangsidimpuan.

Hasil penelitian bahwa dengan terbentuknya Undang-undang Nomor 50 tahun 2009 perubahan atas Undang-undang Nomor 3 Tahun 2006 dan juga perubahan Undang-undang Nomor 7 Tahun 1989 yang mengatur tentang kewenangan Pengadilan Agama telah mengurangi kewenangan dari Pengadilan Negeri untuk memeriksa atau mengadili sengketa-sengketa hukum yang terjadi antara masyarakat yang bergama Islam karena pihak Pengadilan Negeri berhak mengadili dan memeriksa perkara-perkara tentang waris Islam adalah mengenai persengketaan kepemilikan harta warisan tersebut. Pengadilan Negeri untuk menyidangkan sengketa warisan Islam khususnya tentang masalah yang berkaitan dengan sengketa kepemilikan harta warisan adalah bersifat mutlak akan tetapi pelaksanaan putusan yang dikeluarkan berdasarkan kewenangan Hakim Pengadilan Negeri yang sesuai dengan apa yang terdapat di dalam Undangundang Nomor 48 Tahun 2009.
\end{abstract}

Kata Kunci : Kewenangan Hakim, Pengadilan Negeri, Warisan

tersebut. Hak dan kewajiban tersebut

\section{Pendahuluan}

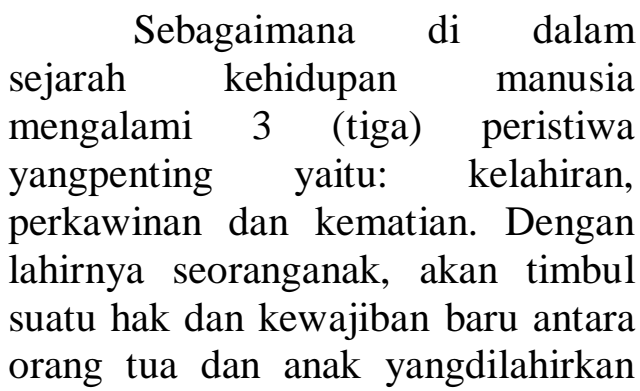
melekat hingga anak tersebutdewasa, sehingga pada waktu phase berikutnya yaitu perkawinan. Perkawinan merupakan basis masyarakat yang baik dan teratur yang tidakhanya diikat oleh ikatan lahir tetapi juga diikat oleh ikatan batin dan jiwa. Salahsatu tujuan dari perkawian adalah memperoleh keturunan yang sah, dan 


\section{http://jurnal.um-tapsel.ac.id/index.php/nusantara}

pulasebagaimana kondisi manusia yang normal, perkawinan tersebut akanmenghasilkan anak, anak inilah yang kelak dikemudian hari akan melanjutkansejarah dan nama keluarga, maka si anak inilah yang dinamakan sebagai ahliwaris dan ia berhak atas segala hal yang ditinggalkan orang tuanya, jika kelakorang tua mereka meninggal dunia

$\begin{array}{lrr} & \text { Setelah si anak ditinggal mati } \\ \text { orang } & \text { tuanya, } & \text { akan } \\ \text { mengakibatkantimbulnya } & \text { suatu }\end{array}$
goncangan atau suatu gangguan keseimbangan kehidupan, baik didalam kehidupan masyarakat, lingkungan maupun diantara keluarga sendiri.gangguan itu pada mulanya rasa sedih atas kematian orang tuanya, kemudian adaanggota keluarganya yang merasa dirinya "waris" dari orang yang meninggaldunia. Dengan demikian mereka akan membicarakan tentang pewarisan pada harta yangditinggalkan oleh pewaris dan juga membicarakan tentang bagaimana caramenyelesaikan hubungan-hubungan hukum yang ada antara orang yangmeninggal dunia (di dalam hal ini disebut pewaris), dan keluarga yangditinggalkan (ahli waris). Pada hakekatnya hubungan-hubungan hukum yangdiselesaikan itu berupa hak dan kewajiban baik yang dapat dinilai dengan uangmaupun yang tidak dapat dinilai dengan uang (non materil)

\section{Sebagaimana}

yang

dikemukakan oleh A Pitlo hukum waris adalah : "kumpulan peraturan yang mengatur mengenaikekayaan yang ditinggalkan oleh si mati dan akibat hukum dari perpindahantersebut bagi yang memperolehnya, baik dalam hubungan antara mereka denganmereka, maupun dalam hubungan antaramereka dengan pihak ketiga. Pada asasnya hak-hak dan kewajiban-kewajiban hukum dalamlapangan hukum kekayaan atau harta benda saja yang dapat diwariskan, sebagaimana yang dijelaskan oleh Efendi Perangin yaitu : “Adabeberapa kekecualian, misalnya hak seorang bapak untuk menyangkal sahanaknya untuk menuntut supaya ia dinyatakan anak yang sah dari bapak atauibunya (kedua hak itu adalah dalam lapangan hukum kekeluargaan),dinyatakan dalam undang-undang diwarisi oleh ahli warisnya.

Namun di dalam hukum Indonesia, pewarisan dengan menganut sistem individual, dimana harta warisan tersebut harus segera dibagikan dan setiap ahli waris mendapatkan pembagian warisan untuk dapat menguasai atau memiliki harta warisan menurut bagiannya masing-masing. Seperti yang dijelaskan oleh Hilman hadikusumayaitu : "Adapun harta warisan ini kemudian diadakan yang berakibat para waris dapat menguasai dan memiliki bagian untuk dapat dinikmati, diusahakan ataupun, dialihkan kepada anggota kerabat, ataupun orang lain”. Dengan demikian hukum sebagai sarana yang diperlukan untuk menegakkan keadilan, kebenaran dan kepastian atas hak-hak yang dimiliki seseorang harus mampu memberikan pengayoman di dalam mana seseorang tersebut menggunakan serta menikmatinya. Maka sejalan dengan itulah saat menerapkan hukum berlaku di tengah-tengah masyarakat harus diselaraskan 


\section{http://jurnal.um-tapsel.ac.id/index.php/nusantara}

dengan kebiasaan atau budaya masyarakat itu sendiri

Berdasarkan tersebut di atas oleh sebab itu pula ditegaskan bahwa peradilan Agama berdasarkan Undang-undang Nomor 50 Tahun 2009 merupakan salah satu pelaksanaan kekuasaan kehakiman bagi rakyat pencari keadilan yang beragama Islam mengenai perkara perdata yang artinya setiap persoalan hukum yang menyangkut hukum Islam seperti masalah pembagian harta warisan harus diselesaikan dengan melalui proses peradilan agama. Akan tetapi dalam kenyataan yang berkembang dalam masyarakat sampai dengan sekarang masih banyak mengajukan persoalanpersoalan hukum Islam seperti pembagian warisan ini dengan melalui jalur Pengadilan Negeri dan pada kenyataannya pula aparat Pengadilan Negeri sendiripun masih menerima hal ini sebagai suatu kewenangannya.

\section{Metode Penelitian}

Penelitian ini dilaksanakan di Kantor Pengadilan Negeri Padangsidimpuan. Jenis penelitian yang digunakan yaitu dengan penelitian normatif suatu penelitian yang didasarkan kepada peraturan perundang-undanagan serta putusan dari pengadilan yang ada kaitannya dengan masalah yang dihadapi dalam penelitian ini. Teknik atau alat yang digunakan dalam mengumpulkan data baik dilapangan maupun dalam melakukan wawancara dengan responden.

\section{Pembahasan}

\section{Kewenangan Pengadilan Negeri Mengadili Perkara Warisan Setelah Berlakunya Undang-undang Nomor $\mathbf{5 0}$ Tahun 2009}

Berlakunya Undang-undang Nomor 50 tahun 2009 perubahan atas Undang-undang 3 Tahun 2006 dan perubahan Undang-undang Nomor 7 Tahun 1989 untuk mengatur status dan kewenangan Pengadilan Agama sebagai Pengadilan bagi orang-orang yang beragama Islam kiranya telah menempatkan keberadaan Pengadilan pada Proforsi yang sebagaimana ditentukan pada Pasal 1ayat (5) Undang-undang Nomor 48 Tahun 2009 secara tegas diatur bahwa selalu empat badan peradilan yang terdapat di Indonesia ini juga dimana peradilan Agama telah dinyatakan sebagai suatu badan hukum yang berdiri sendiri sejajar dengan dengan badan peradilan lainnya seperti peradilan umum, peradilan militer, peradilan tata usaha negara dan oleh sebuah Mahkamah Konstitusi.

Sehubungan dengan itulah seperti yang ditegaskan oleh Hakim Pengadilan Negeri Padangsidimpuan bahwa khusus masalah warisan yang berhubungan dengan orang-orang yang menganut agama Islam adalah kewenangan dari Peradilan Agama yang mana hal ini secara tegas diatur dalam ketentuan Pasal 49 Undangundang Nomor 50 Tahun 2009 maupun dalam Undang-undang Nomor 3 tahun 2006 dan Undangundang Nomor 7 Tahun 1989 tersebut

Sehubungan dengan ketentuan tersebut dengan adanya istilah semua pada rumusan itu jelas memberikan kewenangan bagi Pengadilan Negeri untuk mengadili 
atau menyidangkan semua bentuk perkara atau dengan kata lain tidak ada alasan untuk tidak memeriksa di hadapan sidang Pengadilan. Kemudian lebih lanjut Hakim Pengadilan Negeri Padangsidimpuan menegaskan bahwa juga dasar kewenangan tersebut ditentukan dalam Pasal 10ayat (1) Undangundang Nomor 48 Tahun 2009 yang mengatakan bahwa pengadilan tidak boleh menolak untuk memeriksa, mengadili dan memutus suatu perkara yang diajukan dengan dalih bahwa hukum tidak ada atau kurang jelas melainkan wajib untuk memriksa dan mengadilinya.

Dengan kata lain jika seandainya para pihak berperkara baik penggugat maupun tergugattergugat keberatan disidangkan di Pengadilan Negeri akan mengajukan eksepsi tentang hal ini, sedangkan eksepsi yang diajukan oleh para tergugat dan turut tergugat telah ditolak oleh Hakim Pengadilan Negeri, sesuai dengan ketentuan Pasal 10 ayat (2) yang menerangkan bahwa tidak menutup usaha untuk penyelesaian perkara perdata secara damai atau dengan kata lain memerintahkan kepada para pihak yang berperkara untuk melanjutkan pemeriksaan perkara ini.

Dimana dalam ketentuan Pasal 10 tersebut di atas telah dibatasi kewenangan Pengadilan Negeri untuk mengadili masalahmasalah warisan Islam yaitu apabila di dalam sengekata tersebut terdapat sengketa hak milik atas obyek yang disengketakan barulah Pengadilan Negeri berwenang, sedangkan jika sengketa ini khususnya persoalan pembagian diantara para ahli waris hal itu mutlak wewenang Pengadilan Agama. Lebih lanjut di tegaskan oleh Hakim Pengadilan Negeri
Padangsidimpuan bahwa untuk memperkuat penjelasan di atas dapat dibandingkan dengan salah satu Yurisprudensi Mahkamah Agung RI, Nomor 11.K/AG/1979 menegaskan bahwa apabila dalam suatu gugatan yang menyangkut pembagian harta warisan masih terkandung sengketa hak milik maka perkara yang ebrsangkutan tidak termasuk kewenangan Pengadilan Agama untuk memeriksanya tetapi termasuk kewenangan Pengadilan Umum (Negeri).

Berdasarkan uraian tersebut di atas, maka dengan demikian apa yang ditetapkan Hakim Pengadilan Negeri Padangsidimpuan dalam amar putusannya yang menyatakan bahwa tentang eksepsi kewenangan mengadili (Eksepsi Abosolut) yang diajukan oleh para tergugat-tergugat ditolak oleh Hakim karena di dalam isi eksepsi tergugat menyatakan bahwa Pengadilan Negeri Padangsidimpuan tidak ada kewenangan Pengadilan Negeri untuk menyidangkan, memeriksa dan memutuskan persengketaan tersebut dan juga mengatakan gugatan penggugat kurang pihak serta gugatan dari penggugat kabur dan tidak jelas

\section{Kewenangan Pengadilan Negeri Mengadili Warisan Islam Setelah Berlakunya Undang-undang Nomor 50 Tahun 2009}

Sebagaimana dijelaskan dalam uraian terdahulu bahwa kewenangan Pengadilan Negeri dengan dasar penentuan dalam Undang-undang Nomor 48 Tahun 2009 jelas merupakan rangkaian azas kebebasan Hakim untuk menentukan sendiri apakah berwenang mengadili sesuatu perkara atau tidak, maka dalam kaitan itulah sekalipun telah 
berlakunya Undang-undang Nomor 50 Tahun 2009 yang menyatakan bahwa setiap sengketa pembagian harta warisan Islam adalah berada di bawah wewenang Pengadilan Agama ternyata Pengadilan Negeri tidak pernah merasa bahwa tidak berwenang untuk mengadili sengketa harta warisan akan tetapi yang diperiksa dan diadili oleh Pengadilan Negeri Padangsidimpuan adalah merupakan persengketaan tentang hak milik bukan masalah pembagian harta warisan karena Pengadilan Negeri Padangsidimpuan adalah cuman bersifat relatif kompetitif

Berdasarkan alasan Undangundang tersebut itulah menurut Hakim Pengadilan Negeri Padangsidimpuan kewenangan Pengadilan Negeri tetap berkekuatan hukum untuk mengadili sengketa warisan Islam dalam bentuk sengekata yang bagaimanapun baik itu menyangkut sengketa warisan yang pada umumnya adalah persengketaan mengenai hak kepemilikan harta warisan tersebut dan bukan mengenai masalah pembagian harta warisan. Adapun alasannya dinyatakan demikian lebih lanjut Hakim Pengadilan Negeri Padangsidimpuan menyatakan adalah dikarenakan tidak satupun aturan Undang-undang yang melarang atau mencabut kewenangan Pengadilan Negeri mengadili sengketa masalah warisan Islam yaitu dengan dasar ketentuan Pasal 10 ayat (1) Undang-undang Nomor 48 Tahun 2009 yang menyatakan bahwa tidak boleh menolak untuk memeriksa, mengadili dan memutus suatu perkara yang diajukan dengan dalih bahwa hukum tidak ada atau kurang jelas melainkan wajib untuk memeriksa dan mengadilinya. Akan tetapi sekalipun tidak ketentuan yang menyebut kewenangan Pengadilan Negeri sebagaimana dijelaskan di atas namun menurut Hakim Pengadilan Negeri Padangsidimpuan mengatakan seharusnya dapat mempertimbangkannya dengan alasan ketentuan Pasal 50 Undangundang Nomor 50 Tahun 2009 bahwasanya sudah jelas dikatakan apabila terjadi sengketa hak milik atau sengketa lain dalam perkara sebagaimana dimaksud dalam Pasal 49, khusus mengenai obyek sengketa tersebut harus diputus lebih dahulu oleh Pengadilan dalam lingkungan Peradilan Umum.Sehubungan dengan itulah lebih lanjut dikatakan bahwa dengan ketentuan tersebut sudah jelas dan tegas kewenangan Pengadilan Negeri dalam bindang sengketa kepemilikan harta warisan sudah tidak ada keraguan lagi bahwasanya yang diperbolehkan Undang-undang hanyalah untuk memriksa persengketaan saja dan bukan untuk melaksakan sebagaimana yang ditentukan dalam Pasal 49 Undang-undang Nomor 50 Tahun 2009 tersebut.

Sesuai dengan hal tersebut di atas dimana alasan itulah apa yang telah dilakukan Hakim Pengadilan Negeri terhadap perkara harta warisan dengan menetapkan dalam amar putusannya menolak eksepsi tentang kewenangan mengadili (Eksepsi Absolut) dari tergugat dan menyatakan Pengadilan Negeri Padangsidimpuan berwenang memeriksa dan mengadili perkaraini, serta memerintahkan kepada para pihak yang berperkara untuk melanjutkan pemeriksaan perkara ini yang telah mempunyai kekuatan hukum tetap. Sebagaimana yang diuraikan tersebut di atas benar jika hanya ditinjau dari ketentuan Undang-undang Peradilan Agama 


\section{http://jurnal.um-tapsel.ac.id/index.php/nusantara}

sebagai Undang-undang yang mengatur kewenangan mereka untuk mengadili suatu perkara, akan tetapi sebaliknya jika ditinjau dari Undangundang yang mengatur kewenangan Pengadilan Negeri untuk menerima dan menyidangkan perkara-perkara perdata juga mempunyai atauran tersendiri yaitu sebagaimana yang diatur dalam Undang-undang Nomor 48 Tahun 2009

Untuk jelasnya menurut
Hakim Pengadilan
Padangsidimpuan menegaskan apa yang diatur dalam penjelasan Pasal 1 Undang-undang Nomo 48 Tahun 2009 bahwa kebebasan dalam melaksanakan wewenang yudisial bersifat mutlak karena tugas Hakim adalah untuk menegakkan hukum dan keadilan berdasarkan Pancasila sehingga putusannya mencerminkan rasa keadilan Rakyat Indonesia. Berdasarkan seluruh keterangan data tersebut di atas kiranya jelaslah bagaimana persoalan kewenangan dari Pengadilan Negeri untuk mengadili perkara-perkara warisan setelah berlakunya Undang-undang Nomor 50 Tahun 2009 yang di dalamnya mengatur secara jelas bahwa kewenangan Pengadilan Negeri hanya terbatas pada sengketa hak milik diantaranya para ahli waris yang bersengketa.

\section{Pertimbangan Hakim Pengadilan Negeri Dalam Kewenangan Mengadili Warisan Islam Setelah Berlakunya Undang-undang Nomor 50 Tahun 2009}

Dengan memperhatikan seluruh data-data tentang masalah kewenangan untuk mengadili perkara-perkara warisan Islam jelas dengan berlakunya Undang-undang Nomor 50 tahun 2009 atas perubahan
Undang-undang Nomor 3 tahun 2006 dan juga perubahan Undang-undang Nomor 7 Tahun 1989 dimana dikatakan bahwa kewenangan Pengadilan sejauh hal itu menyangkut pembagian harta waarisan untuk masing-masing ahli waris, dengan kata lain sebaliknya jika dalam masalah harta warisan tersebut ada yang terselip sengketa hak milik barulah menjadi wewenang Pengadilan Negeri. Kemudian keharusan tersebut juga diperkuat dengan adanya permohonan pihak penggugat kepada Mejalis di dalam gugatannya agar diperiksa sesuai dengan aturan hukum yang berlaku, yang menyatakan bahwa penggugat agar kiranya suatu hari menentukan persidangan dalam perkara dan menyuruh pemanggilan pihak berperkara untuk menghadap dipersidangan guna untuk memeriksa dan mengadilinya. Berdasarkan permohonan dari penggugat sebagaimana dijelaskan di atas menurut Hakim Pengadilan Negeri Padangsidimpuan merupakan suatu bukti bahwasanya perkara tersebut harus disidangkan di Pengadilan Negeri, yang mana hal ini di dasarkan kepada azas bahwa setiap orang dapat menentukan dan memilih melalui Pengadilan Agama atau Pengadilan Negeri ia kan menuntut haknya.

$$
\text { Akan tetapi selanjutnya }
$$
menurut salah seorang Hakim Pengadilan Negeri Padangsidimpuan tersebut di atas menjelaskan bahwa keberadaan azas untuk menuntut hak tersebut memang diakui keberadaannya dalam hukum dan sepenuhnya diberikan kebebasan bagi setiap pencari keadilan untuk menentukannya, namun dengan adanya Undang-undang yang telah 


\section{http://jurnal.um-tapsel.ac.id/index.php/nusantara}

mengatur acara bagi masyarakat menuntut haknya jelas azas tersebut harus dikesampingkan yang artinya penyelesaian sengketa tersebut harus dikembalikan kejalur peraturan yang sudah secara positif dinyatakan berlaku. Berdasarkan alasan itu untuk membuktikan bahwa Hakim pada Pengadilan Negeri tidak berwenang untuk memeriksanya dan mengadilinya, apalagi alasan ini dihubungkan dengan keterangan penggugat yang dijadikan Hakim sebagai suatu pertimbangan yang berbunyi bahwa harta milik penggugat adalah harta warisan dari orang tua penggugat Alm. Mustafa Kemal Harahap Gelar, Sutan Palaon Muda Harahap dimana harta tersebut berasal dari peninggalan Alm. Ompung Nauli Baginda Mangalanggar Harahap sebagaimana tertera dalam surat wasiat tertanggal 1 April 1973.

Karena menurut Hakim Pengadilan Negeri Padangsidimpuan bahwasanya keterangan penggugat dalam pertimbangan tersebut di atas menunjukkan kejelasan masalah yang menjadi sengketa adalah persoalan pemilikan harta warisan yang diperolehnya dari orang tua penggugat Alm Mustafa Kemal Harahap, gelar Sutan Palaon Muda Harahap. Akan tetapi kenyataanya sebagaimana dijelaskan tersebut di atas menurut Hakim Pengadilan Negeri Padangsidimpuan telah dijadikan dasar pertimbangan apda putusan Nomor. 12/Pdt.G/2005/PN.Psp yang berbunyi menolak eksepsi tentang kewenangan mengadili (Eksepsi Absolut) dari tergugat, menyatakan Pengadilan Negeri Padangsidimpuan berwenang memeriksa dan mengadili perkara ini, memerintahkan kepada para pihak yang berperkara untuk melanjutkan pemeriksaan perkara ini dan menangguhkan tentang penentuan besarnya biaya perkara sampai dapa putusan akhir, maka dapat disimpulkan bahwa pada putusan tersebut di atas sudah terjadi putusan yang dinamakan dengan putusan dimana para pihak yang berperkara untuk melanjutkan pemeriksaannya kembali

Lebih lanjut dasar pertimbangan tersebut dilakukan Hakim pada putusannya juga didasarkan kepada pertimbangan lainnya dimana penggugat maupun tergugat telah memberikan jawaban dalam persidangan bahwa pada pokonya membenarkan silsilah keturunan dan harta-harta warisan sehingga membuktikan bahwa benar harta terperkara sebagai harta peninggalan

\section{Kesimpulan}

Adapun kesimpulan yang dapat berhasil ditarik dari penelitian ini adalah sebagai berikut di bawah ini :

1. Bahwa dengan terbentuknya Undang-undang Nomor 50 tahun 2009 perubahan atas Undangundang Nomor 3 Tahun 2006 dan juga perubahan Undang-undang Nomor 7 Tahun 1989 yang mengatur tentang kewenangan Pengadilan Agama telah mengurangi kewenangan dari Pengadilan Negeri untuk memeriksa atau mengadili sengketa-sengketa hukum yang terjadi antara masyarakat yang bergama Islam karena pihak Pengadilan Negeri berhak mengadili dan memeriksa perkara-perkara tentang waris Islam adalah mengenai persengketaan kepemilikan harta warisan tersebut sedangkan 
NUSANTARA : Jurnal Ilmu Pengetahuan Sosial - Vol. 6 No 1 (2019) ( Januari - Juni ) issn online : $2550-0813$ issn cetak : $2541-657 \mathrm{X}$

http://jurnal.um-tapsel.ac.id/index.php/nusantara

Pengadilan Agama adalah Efendi Perangin, 2003. Hukum sudah berhak mengedili dan Waris, Raja Grafindo Persada, memeriksa tentang tata cara Jakarta

pembagian harta warisan.

2. Bahwa kekuatan kewenangan Pengadilan Negeri untuk menyidangkan sengketa warisan Islam khususnya tentang masalah yang berkaitan dengan sengketa kepemilikan harta warisan adalah bersifat mutlak akan tetapi pelaksanaan putusan yang dikeluarkan berdasarkan kewenangan Hakim Pengadilan Negeri yang sesuai dengan apa yang terdapat di dalam Undangundang Nomor 48 Tahun 2009.

\section{DAFTAR PUSTAKA}

A Pitlo, 1984, Hukum Waris, Pramadya Paramita, Jakarta

Benny Bosu. 1994, Buku Pintar Peradilan, Usaha Nasional, Surabaya

Departemen Kehakiman Republik Indonesia, 1989, Bahan Pokok Penyuluhan Tentang Undangundang Dasar 1945, Jakarta

Departemen Kehakiman Republik Indonesia, Undang-undang Nomor 48 Tahun 2009 Tentang Pokok Kehakiman, Jakarta

Departemen Kehakiman Republik Indonesia, 2009, Undang-undang Nomor 49 Tentang Peradilan Umum, Grafitri, Bandung

Departemen Kehakiman Republik Indonesia, 2004, Undang-undang Nomor 4 Tahun 2004 Tentang Pokok Kehakiman, Jakarta

H. Hadari Nawawi, 1990, Metode Penelitian, Raja Grafindo, Jakarta

Hilman Hadikusuma, 2003. Hukum Waris Adat. Citra Aditya Bakti, Bandung

Idris Djakfar. 1995, Kompilasi Hukum Kewarisan, Pustakan Jaya, Jakarta

J. Suprapto, 2007, Mmetodologi Penelitian Hukum, Sinar Grafika, Jakarta

Ny. Retnowulan Sutantio, 1979, Hukum Acara Perdata Dalam Teori Dan Praktek, Alumni, Bandung

Mahkamah Agung RI, 1985, Undang-undang Nomor 14 Tahun 1985 Tentang Mahkamah Agung, Jakarta

muhammad Arief, 1986, Hukum Waris Dalam Islam, Bina Timur, Surabaya

M. Ali Hasan, 1981, Hukum Warisan Dalam Islam, Bulan Bintang, Jakarta

Martiman Prodjohamidjojo. 1984, Kemerdekaan Hakim Keputusan Bebas Murni, Simplex, Jakarta

R. Soeroso, 1993, Praktek Hukum Acara Perdata Tata Cara Dan Proses Persidangan, Sinar Grafika, Jakarta

Roihan A. Rasyid., 1991, Hukum Acara Peradilan Agama, Rajawali, Jakarta 
NUSANTARA : Jurnal Ilmu Pengetahuan Sosial - Vol. 6 No 1 (2019) ( Januari - Juni ) issn online : $2550-0813$ issn cetak : 2541-657X http://jurnal.um-tapsel.ac.id/index.php/nusantara

Sudikno Mertokusumo, 1982, Pengantar Hukum Waris Islam, Sinar Grafika, Jakarta

1982 ,

Hukum Acara Perdata Indonesia, Liberti , Yogyakarta

Sudjana, 2008, Metodologi Penelitian, Sinar Grafindo, Grafindo, Jakarta

Sudarto, 1997, Metodologi Filsafat, Raja Grafindo Persada

Winarno Surakhmad, 1982, Dasar Dan Teknik Research Pengantar Metodologi Ilmiah, Tarsito, Bandung

\section{Undang-undang}

Undang-undang Nomor 50 Tahun 2009 Tentang Peradilan Agama

Undang-undang Nomor 48 Tahun 2009 Tentang Pokok Kekuasaan Kehakiman 